\title{
What time-lag for a retraction search on PubMed?
}

Evelyne Decullier ${ }^{1,2,3^{*}}$, Laure Huot ${ }^{1,2,3}$ and Hervé Maisonneuve ${ }^{4}$

\begin{abstract}
Background: To investigate fraud and errors, scientists have studied cohorts of retraction notices. These researches have been performed using a PubMed search on publication type "retraction of publication" which retrieves the notices of the retractions. We assessed the stability of the indexation of retraction notices over a 15-month period and what was the time-lag to get stability.

Findings: A search on notices of retraction issued in 2008 was repeated every 3 months during 15 months from February 2011. The first search resulted in 237 notices of retraction. Throughout the study period, 14 discrepancies with the initial search were observed $(6 \%)$. We found that the number of retraction notices became stable 35 months after the retraction.
\end{abstract}

Conclusions: The time-lag observed in this study has to be taken into account when performing a PubMed search. Keywords: Retraction, Time-lag

\section{Findings}

To investigate fraud and errors, scientists have studied cohorts of retraction notices [1-6]. These researches have been performed using a PubMed search on publication type "retraction of publication" which retrieves the notices of the retractions. The ability to find all retraction notices published in a given period is essential for these researches, and these studies rely on the fact that all retraction notices are identified as such in PubMed records. If the notification in the journal is labeled as a retraction or withdrawal, NLM will index it as a retraction (http://www.nlm.nih.gov/pubs/factsheets/errata. html). However, indexation process could also be prone to errors. Accuracy of indexation could not be assessed since it would require to have access to the full population of retraction notices, which is actually unknown. We therefore decided to assess the stability of the indexation of retraction notices over a 15-month period and what was the corresponding time-lag.

An initial search on the publication type "retraction of publication" issued in 2008 was performed [6] ("retraction of publication"[Publication Type] AND (“2008”[PDAT]: “2008”[PDAT])). We then repeated it every 3 months during 15 months, from February 2011. Each search was compared to the previous one to find discrepancies, which were classified as: newly identified retraction notice (not indexed in the former search) or change in the retraction's authors. We tried to identify the reason for these changes. These classifications were not defined a priori.

The first search performed in February 2011 resulted in 237 notices of retraction published for the year 2008 . Throughout the study period, 14 discrepancies with the initial search were observed (6\%).

Firstly, 9 notices were newly identified, the last appearing 9 months after the first search (Table 1). Among these, the word "retraction" was present in the title for 6 at the time of the search. Concerning the explanation for the late indexation, in 7 cases, although the e-publication date was in 2008, the publication date of the retraction notice was in 2011, certainly leading to the update of the PubMed record with re-indexation (see Table 2 for an example). In one case, a correction to the retraction notice was issued

\footnotetext{
* Correspondence: evelyne.decullier@chu-lyon.fr

${ }^{1}$ Hospices Civils de Lyon, Pôle Information Médicale Evaluation Recherche, Unité de Recherche Clinique, Lyon F-69003, France

${ }^{2}$ Université de Lyon, EAM Santé Individu Société 4128, Lyon F-69003, France

Full list of author information is available at the end of the article
}

\section{Biomed Central}

(c) 2014 Decullier et al.; licensee BioMed Central Ltd. This is an Open Access article distributed under the terms of the Creative Commons Attribution License (http://creativecommons.org/licenses/by/2.0), which permits unrestricted use, distribution, and reproduction in any medium, provided the original work is properly credited. The Creative Commons Public Domain Dedication waiver (http://creativecommons.org/publicdomain/zero/1.0/) applies to the data made available in this article, unless otherwise stated. 
Table 1 Quaterly PubMed searches during 15 months on 2008 retraction notices

\begin{tabular}{|c|c|c|c|c|c|}
\hline \multirow{2}{*}{$\begin{array}{l}\text { Download } \\
\text { date } \\
\text { feb-2011 }\end{array}$} & \multirow{2}{*}{$\begin{array}{l}\text { \# citations } \\
237\end{array}$} & \multicolumn{3}{|c|}{ Citations modified compared to previous search } & \multirow{3}{*}{$\begin{array}{l}\text { Coding } \\
\begin{array}{l}\text { Newly } \\
\text { identified }\end{array}\end{array}$} \\
\hline & & & & & \\
\hline \multirow[t]{2}{*}{ 22-may 2011} & \multirow[t]{2}{*}{239} & $\begin{array}{l}\text { Wolfort, R.M., Manriquez, R., } \\
\text { Stokes, K.Y., Granger, D.N. }\end{array}$ & $\begin{array}{l}\text { Retraction : Platelet-derived RANTES mediates } \\
\text { hypercholesterolemia-induced superoxide } \\
\text { production and endothelial dysfunction }\end{array}$ & $\begin{array}{l}\text { Arterioscler } \\
\text { Thromb Vasc Biol }\end{array}$ & \\
\hline & & $\begin{array}{l}\text { Wolfort,R.M., Manriquez, R., } \\
\text { Stokes, K.Y., Granger, D.N. }\end{array}$ & $\begin{array}{l}\text { Platelet-derived RANTES mediates } \\
\text { hypercholesterolemia-induced superoxide } \\
\text { production and endothelial dysfunction: retraction }\end{array}$ & $\begin{array}{l}\text { Arterioscler } \\
\text { Thromb Vasc Biol }\end{array}$ & \\
\hline \multirow[t]{3}{*}{ 22-aug-2011 } & \multirow[t]{3}{*}{241} & & Retraction & J Am Soc Nephrol & \multirow{2}{*}{$\begin{array}{l}\text { Newly } \\
\text { identified }\end{array}$} \\
\hline & & & $\begin{array}{l}\text { Retraction notice to "Quantitative role of p42/44 } \\
\text { and p38 in the production and regulation of } \\
\text { cytokines TNF-alpha, IL-1 beta and IL-12 by murine } \\
\text { peritoneal macrophages in vitro by Concanavalin } \\
\text { A "[Cytokine 2007;37:62-70]" }\end{array}$ & Cytokine & \\
\hline & & & $\begin{array}{l}\text { Retraction : Platelet-derived RANTES mediates } \\
\text { hypercholesterolemia-induced superoxide production } \\
\text { and endothelial dysfunction }\end{array}$ & $\begin{array}{l}\text { Arterioscler } \\
\text { Thromb Vasc Biol }\end{array}$ & Authors \\
\hline \multirow[t]{5}{*}{ 22-nov-11 } & \multirow[t]{5}{*}{246} & Toggweiler, S., Erne, P. & $\begin{array}{l}\text { Functional mitral stenosis-a rare complication } \\
\text { of the Impella assist device }\end{array}$ & Eur J Echocardiogr & \multirow[t]{5}{*}{$\begin{array}{l}\text { Newly } \\
\text { identified }\end{array}$} \\
\hline & & Namboodri, N. & $\begin{array}{l}\text { Doppler echocardiographic assessment of TTK } \\
\text { Chitra prosthetic heart valve in the mitral position }\end{array}$ & Eur J Echocardiogr & \\
\hline & & $\begin{array}{l}\text { Reiner, J. L., Nakayama, S. F., } \\
\text { Delinsky, A. D., Strynar, M. J., } \\
\text { Lindstrom, A. B. }\end{array}$ & $\begin{array}{l}\text { Retraction. Method development and measurement of } \\
\text { perfluorinated compounds in U.S. chicken eggs }\end{array}$ & Environ Sci Technol & \\
\hline & & $\begin{array}{l}\text { Oka, H., Yoshioka, M., Morita, } \\
\text { M., Onouchi, K., Mochio, S., } \\
\text { Inoue, K. }\end{array}$ & $\begin{array}{l}\text { Retractions: "Cardiovascular dysautonomia in de } \\
\text { nove Parkinson's disease" J Neurol Sci 2006; 241:59-65 } \\
\text { and "Cardiovascular autonomic dysfunction in dementia } \\
\text { with Lewy bodies and Parkinson's disease" J Neurol } \\
\text { Sci 2007; 254:72-77. }\end{array}$ & J Neurol Sci & \\
\hline & & $\mathrm{Ho}, \mathrm{S}$. & Structure and anatomy of the aortic root & Eur J Echocardiogr & \\
\hline \multirow[t]{3}{*}{$22-f e b-2012$} & \multirow[t]{3}{*}{246} & & $\begin{array}{l}\text { Doppler echocardiographic assessment of TTK Chitra } \\
\text { prosthetic heart valve in the mitral position }\end{array}$ & Eur J Echocardiogr & \multirow[t]{3}{*}{ Authors } \\
\hline & & & $\begin{array}{l}\text { Functional mitral stenosis-a rare complication of the } \\
\text { Impella assist device }\end{array}$ & Eur J Echocardiogr & \\
\hline & & & Structure and anatomy of the aortic root & Eur J Echocardiogr & \\
\hline 23-may-2012 & 246 & & $\begin{array}{l}\text { Retraction. Method development and measurement } \\
\text { of perfluorinated compounds in U.S. chicken eggs }\end{array}$ & Environ Sci Technol & Authors \\
\hline
\end{tabular}

in 2011, certainly leading to the modification of the initial indexation of the notice. For 1 case, we could not find any explanation for the late indexation.

Secondly, a total of 5 discrepancies on the author list was observed. They consisted in the deletion of the author list initially available (Table 1 ). All these modifications occurred in notices which were newly identified during our study.

We found that the number of retraction notices became stable in November 2011 for the retraction notices of the year 2008 i.e., 35 months after. This result shows that retraction notices, despite being a very specific entity, are not always indexed as "retraction of publication" in PubMed. However, as raised by Ivan Oransky (http://retractionwatch.com/), there is no other available database for retractions.

The time-lag observed in this study has to be taken into account when performing a PubMed search and a time-lag of at least 3 years should be respected between the time of the search and the year of interest.

Errors in indexation were corrected when the PubMed record had to be updated (publication, erratum), consequently we cannot ascertain that all retraction notices are indexed as such. Therefore, to ease indexation process, retraction notices titles should at least include the word "retraction" as recommended by the Committee on Publication Ethics (COPE) [7]. Furthermore, the use of a standard retraction form would be very useful 
Table 2 Example of an e-publication date in 2008 and a publication date in 2011 and the corresponding Medline indexation*

\begin{tabular}{|c|c|}
\hline \multicolumn{2}{|c|}{$\begin{array}{l}\text { Reference: Environ Sci Technol. } 2011 \text { Sep 15; } 45 \text { (18):7949. Epub } \\
2008 \text { Jul } 23 .\end{array}$} \\
\hline PMID & 21910498 \\
\hline OWN & NLM \\
\hline STAT & MEDLINE \\
\hline DA & 20110913 \\
\hline DCOM & 20120308 \\
\hline IS & 1520-5851 (Electronic) \\
\hline IS & 0013-936X (Linking) \\
\hline $\mathrm{Vl}$ & 45 \\
\hline IP & 18 \\
\hline DP & 2011 Sep 15 (publication date) \\
\hline $\mathrm{Tl}$ & $\begin{array}{l}\text { Retraction. Method development and measurement of } \\
\text { perfluorinated compounds in U.S. chicken eggs }\end{array}$ \\
\hline PG & 7949 \\
\hline LA & eng \\
\hline PT & Retraction of Publication \\
\hline DEP & 20080723 (e-publication date) \\
\hline$P L$ & United States \\
\hline TA & Environ Sci Technol \\
\hline JT & Environmental science \& technology \\
\hline$J I D$ & 0213155 \\
\hline SB & $\mathrm{IM}$ \\
\hline ROF & Environ Sci Technol. doi:10.1021/es800770f \\
\hline EDAT & $\begin{array}{l}\text { 2011/09/14 06:00 (Input date, or publication date } \\
\text { when recorded more than } 12 \text { months after publication) }\end{array}$ \\
\hline MHDA & 2012/03/09 06:00 \\
\hline CRDT & 2011/09/14 06:00 \\
\hline PHST & 2008/07/23 [aheadofprint] \\
\hline AID & 10.1021/es800770f [doi] \\
\hline PST & ppublish \\
\hline so & Environ Sci Technol. 2011 Sep 15;45(18):7949. Epub 2008 Jul 23. \\
\hline
\end{tabular}

*PubMed link explaining fields: http://www.nlm.nih.gov/bsd/mms/ medlineelements.html\#edat.

as it could help to standardize the title as well as the way of presenting authors for retractions [6].

\section{Competing interest}

The authors declare that they have no competing interests.

\section{Authors' contributions}

ED declares that she designed the study, performed the searches, analysed the data, interpreted the data and wrote the manuscript. LH declares that she designed the study, participated in drafting the manuscript and that she has read and approved the final version. HM declares that he participated in drafting the manuscript and that he has read and approved the final version. All authors read and approved the final manuscript.
Authors' information

ED is a senior researcher (PhD), LH is a senior researcher (PharmD, PhD), HM is a senior researcher (MD)

\section{Author details}

${ }^{1}$ Hospices Civils de Lyon, Pôle Information Médicale Evaluation Recherche, Unité de Recherche Clinique, Lyon F-69003, France. ${ }^{2}$ Université de Lyon, EAM Santé Individu Société 4128, Lyon F-69003, France. ${ }^{3}$ Université Lyon 1, Lyon F-69003, France. ${ }^{4}$ Public Health Department, Paris-Sud 11 University, Paris, France.

Received: 20 November 2013 Accepted: 13 June 2014

Published: 25 June 2014

\section{References}

1. Wager E, Williams $P$ : Why and how do journals retract articles? an analysis of Medline retractions 1988-2008. J Med Ethics 2011, 37(9):567-570.

2. Steen RG: Retractions in the scientific literature: is the incidence of research fraud increasing? J Med Ethics 2011, 37(4):249-253.

3. Nath SB, Marcus SC, Druss BG: Retractions in the research literature: misconduct or mistakes? Med J Aust 2006, 185(3):152-154.

4. Budd JM, Sievert M, Schultz TR: Phenomena of retraction: reasons for retraction and citations to the publications. JAMA 1998, 280(3):296-297.

5. Redman BK, Yarandi HN, Merz JF: Empirical developments in retraction. $J$ Med Ethics 2008, 34(11):807-809.

6. Decullier E, Huot L, Samson G, Maisonneuve H: Visibility of retractions: a cross-sectional one-year study. BMC Res Notes 2013, 6:238.

7. COPE: Retraction guidelines. 2009, http://www.publicationethics.org/files/ retraction\%20guidelines.pdf.

doi:10.1186/1756-0500-7-395

Cite this article as: Decullier et al:: What time-lag for a retraction search on PubMed? BMC Research Notes 2014 7:395.

\section{Submit your next manuscript to BioMed Central and take full advantage of:}

- Convenient online submission

- Thorough peer review

- No space constraints or color figure charges

- Immediate publication on acceptance

- Inclusion in PubMed, CAS, Scopus and Google Scholar

- Research which is freely available for redistribution
() Biomed Central 